\title{
Degrowth: culture, power and change
}

\author{
Susan Paulson ${ }^{1}$ \\ University of Florida, USA
}

\begin{abstract}
Harmful environmental consequences of growth have been rigorously documented and widely publicized throughout the past half-century. Yet, the quantity of matter and energy used by human economies continues to increase by the minute, while governments and businesses continue to promise and to prioritize further economic growth. Such a paradox raises questions about how we humans change course. This introduction to a Special Section offers a new theoretical approach to change, together with glimpses of adaptations underway around the world. It directs attention away from individual decision-making and toward systems of culture and power through which socialized humans and socioecological worlds are (re)produced, sustained and adapted. Potential for transformative change is found in habitual practices through which skills, perspectives, denials and desires are viscerally embodied, and in cultural systems (economic, religious, gender and other) that govern those practices and make them meaningful. Case studies reviewed illuminate diverse communities acting to maintain old and to forge new moral and material worlds that prioritize wellbeing, equity and sustainability rather than expansion. This article endeavors to galvanize change by conceptualizing degrowth, by decolonizing worldviews of expansionist myths and values, and by encouraging connections between science and activism, north and south.
\end{abstract}

Key words: degrowth, transition, climate change, socioecological systems

\section{Résumé}

Les conséquences environnementales négatives de la croissance ont été rigoureusement documentées et largement médiatisées pendant un demi-siècle. Pourtant, la quantité de matière et d'énergie utilisée par les économies humaines continue d'augmenter de minute en minute, tandis que les gouvernements et les entreprises continuent d'accorder la priorité et de promettre une croissance économique accrue. Un tel paradoxe soulève des questions sur la manière dont les humains changent. Cette introduction à une Section Spéciale propose une nouvelle approche théorique au changement, ainsi que des aperçus d'adaptations en cours dans le monde. Elle détourne l'attention de la prise de décision individuelle vers les systèmes de culture et de pouvoir par lesquels les êtres socialisés et les mondes socio-écologiques sont (re)produits, soutenus et adaptés. Une attention particulière est accordée aux pratiques habituelles par lesquelles les compétences, les perspectives, les démentis et les désirs sont viscéralement incarnés, et aux systèmes culturels (économiques, religieux, de genre et autres) qui régissent ces pratiques et les rendent significatives. Les études de cas ont permis d'éclairer les expériences de diverses communautés qui agissent pour préserver l'ancienne et de forger de nouveaux mondes moraux et matériels qui ne sont pas axés sur l'expansion, mais plutôt le bien-être, l'équité et la durabilité. Cet article s'efforce de soutenir le changement en conceptualisant le décroissement; décoloniser les visions du monde à partir de mythes et de valeurs expansionnistes; et encourager les liens entre la science et l'activisme, au nord et au sud.

Mots clés: décroissance, transition, changement climatique, systèmes socioécologiques

\footnotetext{
${ }^{1}$ Dr. Susan Paulson, Professor of Latin American Studies, University of Florida. Email: spaulson "at" latam.ufl.edu. I am grateful for inspiration and insight from dialogue with all contributors to this Special Section, amid a wider network of participants in sessions at American Anthropology Association meetings 2015 and 2016, at the International Degrowth Conference 2016, and in University of Florida's group on 'Postdevelopment pathways.' Thanks for judicious support from JPE editors Casey Walsh and Simon Batterbury, and for astute questions from Lisa Gezon, Martha Huang and Jack Putz. This is the introductory article in Lisa L. Gezon and Susan Paulson (eds.) 2017. "Degrowth, culture and power", Special Section of the Journal of Political Ecology, 24: 425-666.
} 


\section{Resumen}

Las consecuencias ambientales negativas del crecimiento han sido rigurosamente documentadas y ampliamente publicitadas durante medio siglo. Sin embargo, la cantidad de materia y energía utilizada por las economías humanas sigue aumentando a cada minuto, mientras que los gobiernos y las empresas siguen priorizando y prometiendo un mayor crecimiento económico. Tal paradoja plantea preguntas acerca de cómo los humanos cambian de rumbo. Esta introducción a una sección especial ofrece un nuevo enfoque teórico para el cambio, y vislumbra adaptaciones en curso alrededor del mundo. Dirija la atención no a la toma de decisión individual, sino hacia los sistemas de cultura y poder a través de los cuales los seres humanos socializados y los mundos socioecológicos son (re)producidos, sostenidos y adaptados. Se encuentra potencial de tranformación en las prácticas habituales a través de las cuales las habilidades, perspectivas, negaciones y deseos se encarnan visceralmente, y en los sistemas culturales (económicos, religiosos, de género y otros) que gobiernan esas prácticas y las hacen significativas. Los estudios de caso examinan las experiencias de diversas comunidades que actúan para mantener antiguos y forjar nuevos mundos prácticos, morales y materiales que no están orientados a la expansión, sino que priorizan el bienestar, la equidad y la sostenibilidad. Este artículo intenta apoyar el cambio mediante un esfuerzo para conceptualizar el decrecimiento; descolonizar las cosmovisiones, mitos y valores expansionistas; y alentar las conexiones entre la ciencia y el activismo, el norte y el sur.

Palabras clave: decrecimiento, transición, cambio climático, sistemas socioecologicos

\section{Introduction}

A surge of experimentation in search of more just and sustainable futures launched the term "degrowth" into late $20^{\text {th }}$ century politics, science and social movements. Envisioned as a path forward involving "an equitable downscaling of production and consumption that increases human well-being and enhances ecological conditions" (Schneider, Martinez-Alier and Kallis 2010: 511), the idea has provoked debate in political parties and national elections, been embraced by Via Campesina and People's Summits on Climate Change, and activated in anti-globalization and occupy movements, and in a spectrum of local initiatives. Following decades of discussion and publication centered mainly in Europe, degrowth has also erupted in wider scholarly conversations, headlining a couple hundred journal articles and dozens of books.

The magic of degrowth lies in its ability to energize and connect remarkably heterodox thinking and surprisingly heterogeneous action, including that of non-dominant groups. Therein also lies the challenge for our conventional minds. Indeed, we participants in this Special Section struggled against a tendency to portray degrowth as a single voice: "degrowth argues X," "degrowers deny Y," and "degrowth fails to consider Z." Conspicuously absent, however, among the sundry aims associated with the term is ambition to consolidate an orthodox scientific paradigm or a unified political platform. Instead, degrowth is embraced as a banner under which actors and movements gather from sources as diverse as ecological economics and green theology, in pursuit of goals ranging from increasing democracy to reducing climate change. It should come as no surprise, then, that debates about what degrowth is, is not, or ought to be entail extraordinary theoretical and normative complexity.

So, I begin locally with three understandings shared by authors in this Special Section as we think together about past processes and paths forward. First, ideas of degrowth provoke us to ask how imperatives and mechanisms of growth impact specific political ecologies. Second, ideals of degrowth call us to shift value and desire away from productivist achievements and consumption-based identities toward visions of good life variously characterized by health, harmony, pleasure and vitality among humans and ecosystems. Third, and most tangibly, we live degrowth as a multi-sited, multilingual and multiform network supporting the opportunity for lifeways motivated by desires other than growth to survive and to thrive in the shadow of those forms that dominate contemporary societies.

This Special Section has taken shape via dialogue among 17 authors from an extraordinary range of cultural and linguistic backgrounds, representing formation in anthropology, geography, human ecology, political science, sociology and sustainability studies. Together we explore phenomena playing out in 13 countries, some of which boast prodigious growth (Faroe Islands, Finland, Germany, New Zealand), while others face situations of postgrowth (Japan and Italy) or postdevelopment (Perú), or seem to have missed the growth boom altogether (Madagascar, Bhutan). Some of our studies consider low-income, low-consumption people and places within powerful national economies (Atlantic Canada; Bahia, Brazil; Chiapas, Mexico; and Missouri and North Carolina, United States). We have cultivated conversations around these cases in the 
course of three sessions at Meetings of the American Anthropological Association, two sessions at the $5^{\text {th }}$ International Degrowth Conference, and mutual critiques of each other's writings and ramblings.

Each section of this essay addresses challenges explored during our collaborative process: conceptualizing degrowth, material, economic and cultural; innovative science and activism, north and south; the paradox of much information and little transformation; and questions about how humans change. This essay does not pretend to review the long history of seminal ideas nor the recent surge of degrowth-related publications that have inspired and enriched our journey. More comprehensive characterizations can be found in sources including Degrowth: a vocabulary for a new era (D'Alisa, Demaria and Kallis 2014).

\section{What is degrowth?}

Long-evolving concerns about social and ecological costs of growth came to the fore 45 years ago with the publication of seminal books including: Limits of growth (Meadows et al. 1972), The entropy law and the economic process (Georgescu-Roegen 1971), Environment, power and society (Odum 1971), and Framtiden $i$ våre hender (Dammann 1972, translated as The future in our hands, Dammann 1979). Concurrent experiments with ways to change course ranged from UN-led population planning to grassroots hippie communes and vegetarian co-ops, and the launch in Norway of Future in our hands - a people's movement for a new lifestyle and a just distribution of the world's resources. ${ }^{2}$

Degrowth was explicitly conceptualized by a network of thinkers initially centered in France, among them philosopher André Gorz (1980: 13), who wrote: "even at zero growth, the continued consumption of scarce resources will inevitably result in exhausting them completely. The point is not to refrain from consuming more and more, but to consume less and less - there is no other way of conserving the available reserves for future generations." During decades thinking and writing about degrowth, political economist Serge Latouche (2009: 33) came to expound eight principles for a serene and convivial journey: re-evaluate, reconceptualize, restructure, redistribute, relocalize, reduce, re-use and recycle. With the rise of ecological economics, critical focus shifted from consumption to production, including quantitative analyses exposing unequal ecological exchanges that function to subsidize cheap consumer goods and generate profit for investors (e.g. Hornborg and Martinez-Alier 2016; Schor 2005). Today, environmental scientist Giorgos Kallis (2015), a leading force in the burgeoning research network centered in Barcelona, witnesses coexisting efforts to move forward by using degrowth as missile word, slogan, theory, literature, critique, policy, movement, way of life and frontal attack on the ideology of economic growth.

Whereas all these authors promote degrowth as a purposeful project, our studies also draw attention to degrowth sparked by unplanned circumstances, not necessarily welcomed by participants. Differences between "involuntary" and "voluntary" degrowth resemble distinctions between "development" as an immanent historical process and "Development" as a named intentional activity exercised through policies and projects (Bebbington, Hickey and Mitlin 2008; Cowen and Shenton 1998). It must be emphasized, however, that historical processes of economic recession and resource depletion do not, in themselves, equal degrowth; that requires communities and societies to make a virtue out of necessity by building toward lowimpact livelihoods that prioritize well-being and equity. One place such efforts have been explored is Cuba, where abrupt declines in economic and energy inputs impelled by global politics were met by local responses involving agroecology and food sovereignty (Bolliat et al. 2012; Borowy 2013; Rosset et al. 2011). Other relevant contexts are found in Japan and Italy, where years of economic stagnation have prompted calls for urban planning that is neither dependent upon nor aiming toward growth, and where Robin LeBlanc's (2017) article in this Section explores architectural innovations designed to facilitate "beautifully poor" experiences of community and creativity.

This section reviews fiercely-debated ideas about curbing material and economic growth on a macroeconomic scale, setting the scene for discussions of specific cultural practices, relations and identities that have been variously entangled with growth or with efforts to change course. Unable to cover the entire

\footnotetext{
${ }^{2}$ The Future in our hands has grown from 2000 people at the 1974 inaugural meeting to 25,000 members today, maintaining the founding philosophy that each of us can contribute to changing today's ruinous trends if we start by accepting our share of responsibility for the future, and then join others in working for change. Accessed 19 October 2016 http://www.framtiden.no/200502252134/om-oss/in-english/the-origin-of-future-in-our-hands.html
} 
ideascape, I save for another moment relevant debates on population dynamics, unequal ecological exchange, economic and ecological debt, migrants and refugees, and political and financial institutions. ${ }^{3}$

Material degrowth is easy to grasp: it simply means decreasing the quantity of matter and energy transformed each day by the metabolism of human society. In thermodynamic terms, recent boosts in societal metabolism have greatly accelerated anthropogenic entropy, resulting in an array of unwanted outcomes (Georgescu-Rogen 1971; Steffen et al. 2007). Today, global scientists agree that curbing material growth is urgently necessary to mitigate global warming, ocean acidification, biodiversity loss, diminishing fresh water and other crises (IPCC 2013; Steffen et al. 2015). Methodologies developed to measure and monitor the biophysical throughput of societal metabolism include material flows analysis (Fischer-Kowalski and Hüttler 1998; Haberl et al. 2009), embodied energy or "emergy" (Brown 2001; Odum and Odum 2001), human appropriation of net primary production (HANPP) (Haberl et al. 2011; Krausmann et al. 2012) and the more widely recognized ecological footprint (Global Footprint Network 2014; Wackernagel and Rees 1996).

Calls to reduce global ecological footprints are gaining consensus, even among those who have never heard of degrowth. In this Section, Eric Hirsch (2017) describes people scrambling to adapt as their lives are turned upside down by phenomena associated with global warming - melting glaciers in Peru and rising sea waters in the Maldives. Billions of others are affected by earth systems degradation in the form of desertification, deforestation, erosion, desiccation of rivers and springs, depletion of game and fish stock, air and water pollution, and more. Tenacious propensities to blame these phenomena on proximal causes (such as "faulty" local practices, markets, or governance) have been hotly contested since the seminal work of Michael Watts (1983) and Piers Blaikie (1985). Today, an increasing range of actors-including Peruvians and Maldivians studied by Hirsch-are seeking causes and demanding solutions in the rate of societal metabolism and the size of global eco-footprints.

More contention surrounds calls to curb economic growth, the beneficent character of which is cast as self-evident truth at the foundation of right and left-wing politics around the world (e.g. Kohl and Farthing 2012). Is economic growth, in itself, good for humanity? Would economic growth be good if it could be divorced from its negative environmental impacts? Here I question the use of Gross Domestic Product (GDP) as a proxy for other desired outcomes and the prioritization of GDP growth as means to achieve those outcomes, then examine connections between economic growth and material growth.

Indicators of economic growth-defined narrowly as increase in the monetary value of goods and services in a given market—are used by scientists, politicians and development professionals as a proxy for all kinds of desired changes, reinforcing the assumption that rising GDPs automatically produce healthier, happier and wiser citizens. An obvious error of this formula lies in the weak empirical correlation (above extremely low economic thresholds) between higher GDPs and other desired outcomes, such as higher rates of longevity, literacy, equality, security, political participation, mental health, happiness; or lower rates of incarceration, obesity, homicide, suicide (Porter et al. 2016; Sen 1999; Wilkinson and Pickett 2011). On deeper levels, the question of whether economic growth is good for humanity is tangled up in the unequal exchanges that are instrumental to accumulation and growth in current economies, and that produce grossly uneven distributions of their benefits and burdens.

One pragmatic response to that tangle of causality is agnosticism, or a-growth (explored by Latouche 2009; Van de Berg and Kallis 2012; Van de Berg 2011). Rather than pursue economic growth as the means to all good ends, growth agnostics propose refocusing efforts directly toward chosen outcomes. This move liberates societies to advance policies and practices that support well-being in terms valued by each population. A notable example explored in this Section by Ritu Verma (2017) is Bhutan's long-term commitment to building an economy that is not directed to GDP growth, but instead toward attainment of meaningful happiness in harmony with Buddhist spiritual values. Verma's article examines measures that constitute Bhutan's Gross National Happiness Index: health, education, living standards, time use, good governance, ecological diversity and resilience, psychological wellbeing, community vitality, and cultural diversity and resilience.

In some ways more urgent than the question of what good results from economic growth is what damage it brings about by driving material growth. Although expansion of ecological footprints has

\footnotetext{
${ }^{3}$ See my recent article on capitalism and (de)growth, http://www.resilience.org/stories/2016-09-23/capitalism-and-degrowth. Accessed 20 October 2016.
} 
accompanied rising GDPs throughout modern history, future relations between these trajectories are hotly debated. Degrowth advocates urge restraint of global economic and material growth. In contrast, the 18 coauthors of The ecomodernist manifesto (Asafu-Adjaye et al. 2015: 1) proclaim that continuing economic growth will support technological innovations that solve the problems of energy supply, waste and depletion of raw materials: "We offer this statement in the belief that both human prosperity and an ecologically vibrant planet are not only possible, but also inseparable."

Substantial political muscle bolsters campaigns to continue pushing economic growth while striving to "decouple" it from natural resource depletion and pollution. The dream of decoupling has been promoted by influential organizations including The Breakthrough Institute, Ecosystem Marketplace and New Climate Economy, and endorsed by high profile actors including economist Jeffrey Sachs and UN Secretary General Ban Ki-Moon (Fletcher 2016). Further on I praise the United Nations Sustainable Development Goals (SDGs) for communicating unambiguously that all societies-and particularly wealthy ones-must adopt more sustainable paths. Here, however, I point out that SDGs impel what seems to be a dangerous fantasy of decoupling by including goal \#8 "Promote sustained, inclusive and sustainable economic growth . . . ," alongside goals \#13 Climate action, \#14 Life below water, and \#15 Life on land, as if these goals were inherently compatible. My favorite goal, \#10 "Reduce inequality within and among countries," may or may not be achievable in tandem with sustained economic growth, however it should certainly raise questions about correlations over the past 30 years between unprecedented economic growth and precipitous increases in inequalities.

Instead of calling for sustained growth overall, the People and the planet report, produced by a global coalition of 23 scientists under the auspices of the Royal Society (2012), distinguishes needs for growth in some parts of an uneven planet from needs for degrowth in others. Key recommendations start with:

(1) The international community must bring the 1.3 billion people living on less than $\$ 1.25$ per day out of absolute poverty, and reduce the inequality that persists in the world today. (2) The most developed and the emerging economies must stabilize and then reduce material consumption levels. (3) Reproductive health and voluntary family planning programmes urgently require political leadership and financial commitment . . . to continue the downward trajectory of fertility rates. ${ }^{4}$

A rational calculus of efficiency justifies the report's recommendations to promote growth among those living in extreme poverty (where it actually does correlate with improved health, education and other welfare, as well as reduced rates of fertility), and to reduce consumption in wealthier populations (necessary to lower societal metabolism to within planetary boundaries). Its more revolutionary claim is that uneven distribution of wealth and power is, in itself, a fundamental cause of planetary environmental crises. The Royal Society joins others in demonstrating that overconsumption by some has been made possible by exploiting the human and natural resources of others, and by outsourcing environmental damage to less powerful people and places (e.g., Hornborg et al. 2007; Walter and Martinez Alier 2012).

With or without sociospatial displacement of ecological costs and damages, quantitative analyses cast doubt on the ability of current societies to outgrow coupling of economic and material growth through technological innovation alone, without radical political and social change (Daly 1996; Isenhour 2016; Jackson 2009). The hopeful hypothesis of the Environmental Kuznets Curve-that rising GDPs will sustain increasing ecological costs up to a certain level of wealth, after which point further economic growth will actually reduce negative environmental impacts-has fit poorly with empirical evidence since it was proposed in the 1950s. In some contexts, increased efficiency has reduced certain ecological costs per unit of economic gain, however resulting cost savings have consistently led to expansion of net production (echoing the rebound effect of coal consumption first observed by William Stanley Jevons in 1865). In contrast, the potential of concerted political and social change to reduce ecological impacts is demonstrated by Germany's transition to renewable energy (Energiewende) ${ }^{5}$ and EU reduction of $\mathrm{CO}_{2}$ emissions. ${ }^{6}$

\footnotetext{
${ }^{4}$ Accessed 19 October 2016 https://royalsociety.org/topics-policy/projects/people-planet/report.

${ }^{5}$ Accessed 13 November 2016 http://energytransition.de/
} 
To date, then, growth in GDP has corresponded closely with increased environmental impacts in terms of net consumption of resources and net production of waste, including emissions (Sebri 2015; Stern 2004). Yet, like a vampire, the seductive myth that more economic growth will automatically lead to reduced ecological impacts is repeatedly resurrected to justify pushing growth, in spite of collateral damage. The counter-hypothesis - that deceleration of economic growth will automatically rein in ecological footprints, particularly carbon emissions-finds some support in short-term effects of the 2008-2009 global recession (Broder 2011). However, one point on which proponents and critics of growth agree is that, in current growth-based societies, sudden stalls lead to barbaric outcomes.

We know that simply contracting the economy plunges our societies into disarray, increases the rate of unemployment and hastens the demise of the health, social, educational, cultural and environmental projects that provide us with an indispensable minimal quality of life. It is not difficult to imagine the catastrophes that negative growth would bring about! (Latouche 2009: 8)

What we need, argue Latouche and others, is not just a quantitative decrease in production and consumption, but something much more radical: a cultural transformation that re-establishes livelihoods, relationships and politics around a new suite of values and goals. What cultural forms can foster positive and equitable degrowth? What features can mitigate and distribute hardships of change? Who answers these questions? And how?

\section{Innovative science and activism, north and south}

Efforts to question growth and to visualize alternatives have pushed scholars beyond the bounds of mainstream natural and social sciences into engagement with social, political and religious activism, among other modes of enquiry heretofore eschewed as threats to scientific neutrality. Some researchers think about their work in terms of "post-normal science," conceptualized as a problem-solving strategy appropriate "when facts are uncertain, values are in dispute, stakes are high, and decisions urgent" (Funtowicz and Ravetz 1994: 1882). As stakes surrounding socioenvironmental crises become higher and more urgent, while misconnects among values and beliefs generate dangerous conflicts in a world deeply divided by wealth and power, dialogue will become more tense-and perhaps more fruitful—between mainstream scientific approaches and other modes of understanding.

Researchers exercising versions of "normal" and "post-normal" science are combining concepts, methods and information from various disciplines, and advancing transdisciplinary fields like sustainability science and environmental justice. Many draw ideas and inspiration from livelihoods and activists outside of academia, including the most economically marginalized and ecologically imperiled people and places on earth (Martinez-Alier et al. 2014). Arturo Escobar (2015: 452) points to visionary thinkers and ideas emerging amid social movements, non-governmental organizations, and environmental and cultural struggles, while Jonathan DeVore (2015) urges attention to dynamics of power within these realms. Visions evolving in some of these contexts are known as Buen vivir (Latin America), Ecological Swaraj and Radical Ecological Democracy (India), Ubuntu (South Africa) and Gross National Happiness (Bhutan) (e.g., Beling et al. 2014; Bell 2016; Escobar 2009; Gudynas 2011; Kothari 2014; Kothari, Demaria and Acosta 2014; Lang and Mokrani 2013; Shiva 1988; Vanhulst and Beling 2014).

In reciprocal flows, popular movements draw and cultivate ideas, information and support from globally powerful scholars. In a recent instance (May 2016) at La Universidad de la Tierra in Chiapas, I joined 500 others, most in peasant and indigenous dress, gathered to listen to Brazilian theologian Leonardo Boff talk about ethical struggles against growth-obsessed values and their environmental consequences. Boff's message, delivered in Spanish, was translated live into indigenous languages Tzeltal and Tzotzil, reflecting modes through which his writing also travels. Cry of the earth, cry of the poor (Boff 1995, 1997), for example, has been translated formally and informally into dozens of languages. Six months earlier in the

\footnotetext{
${ }^{6}$ Europe 2020 indicators - climate change and energy. Accessed 25 October 2016. http://ec.europa.eu/eurostat/statisticsexplained/index.php/Europe 2020 indicators - climate change and energy.
} 
same locale, Catalan economist and degrowth scholar Joan Martinez-Alier talked about his book The environmentalism of the poor: a study of ecological conflicts and valuation (2003), which has also been taken up by actors in far-reaching languages and localities. Martinez-Alier (2014: 39) makes clear:

Poor people do not always think and behave as environmentalists. To believe this would be blatant nonsense. The environmentalism of the poor arises from the fact that the world economy is based on fossil fuels and other exhaustible resources, it goes to the ends of the earth to get them, disrupting and polluting both pristine nature and human livelihoods, encountering resistance by poor and indigenous peoples who are often led by women.

An astonishing range of sociocultural groups have resisted the penetration of exploitative and polluting enterprises into their lives and territories via actions ranging from struggles against palm oil plantations in Indonesia's rainforests to protests against gas pipelines at North Dakota's Standing Rock Reservation. By cataloguing some 2,000 socio-environmental conflicts, the Environmental justice atlas draws attention to violent repercussions of expanding economic frontiers (Temper et al. 2015). ${ }^{7}$

Jonathan Otto's (2017) article in this Section explores one among many cases in which people living with very low levels of consumption take action against a kind of economic development that seeks to incorporate their labor and other resources into the raw end of value chains. In this case, resistance has been directed against a mega-highway project designed to expand agribusiness and ecotourism in Chiapas, Mexico. Since the Zapatista uprising in 1994, as the North American Free Trade Agreement went into effect, residents of Chiapas have visibly resisted growth-driven development initiatives advanced by the Mexican government. This bold revolutionary front arising from indigenous community and culture surprised observers around the world; even more shocking has been the news that, rather than fighting to gain power in the national political economic machine, Zapatistas seek autonomy from it in order to forge alternative futures.

Since 2006, the Zapatista "Other Campaign" (La otra campaña) has focused on building alliances among voices and visions "from below and to the left," including those expressed among farmers, fishers, factory workers, students, trade unionists, natural disaster victims, and activists for rights of the environment, of women and others (Zapatista Army of National Liberation 2005; Marcos 2006). Rather than confronting growth per se, the Other Campaign defines its work as building a united front against capitalism and neoliberalism. Those broad conversations nourish initiatives like the Decrecimiento México movement launched in 2007 and the seminar "To boost degrowth in Mexico" hosted in 2009 by the environmental network Ecocomunidades. ${ }^{8}$ Back in rural Chiapas, as Otto demonstrates, when Zapatistas organized in 2009 and 2014 to successfully protest a highway project threatening environmental and social degradation along its path, they were joined by nongovernmental organizations, non-Zapatista indigenous and non-indigenous communities, academics and religious figures.

Resources brought to the conversation by Zapatistas and other voices from the global south include metaphors of decolonization and visions of postdevelopment that interweave struggles against political and cultural domination with alternatives to expansionist economies. Some of these visions are communicated in Mahatma Gandhi's message "live simply so others may simply live," in Via Campesina's aim of "food sovereignty" and in the Yasuni cry "leave the oil in the soil."

Concern with harm done to cultural groups and lifeways labeled "underdeveloped" has long provoked criticism of the portrayal of high-growth industrial societies as superior models that should be imitated by or imposed on others (Escobar 1995; Ferguson 1994; Shiva 1988, 2015). Mauro Bonaiuti highlights the role those critiques have played in degrowth thinking.

\footnotetext{
7 EJOLT is a global research project bringing science and society together to catalogue and analyze ecological distribution conflicts and confront environmental injustice. See http://www.ejolt.org/and Environmental Justice Atlas http://ejatlas.org.

${ }^{8}$ Accessed 20 October 2016 https://www.veoverde.com/2010/05/ecosofia-el-decrecimiento-nuestra-unica-posibilidad/, http://decrecimientomexico.blogspot.com/ and http://red-ecomunidades.blogspot.com/2009/08/descrecer-en-mexico2009-para-la.html.
} 
[W] hat characterizes the "criticism of development"-a thread of thought, presented by Ivan Illich (1973), F. Partant (1982), G. Rist (1996), and S. Latouche (2004) that lies at the heart of the prospect of degrowth-is its overturning of the former interpretation of the phenomenon of poverty and exclusion. According to "critics of development," on the basis of evidence of a prevalently historical-social and anthropological nature, the main factor responsible for poverty and exclusion must be sought precisely where it was claimed the solution was to be found--that is, in the process of growth and development. (Bonaiuti 2012: 528)

It has been far more difficult to think critically about harm done along the way to "developed" lifeways and worldviews. As Latouche (2009: 11) emphasizes, societies whose political-economic domination has occasioned global dissemination of their "superior" languages and cultures have-in the process-suffered a crippling colonization of their own imaginaries:

We know that we were seduced into accepting an ethnocentric and ethnocidal concept of development, but it went hand in hand with the violence of colonization and imperialism, and represents what Aminata Traoré eloquently describes as a real "rape of the imaginary" (Traoré 2002).

How can actors and groups located as colonizers and labeled as developed learn from decolonial impulses and postdevelopment visions?

If climate crisis has a silver lining, it may be the power to provoke residents of high-GDP highemission countries to question the portrayal of their own societies as "developed, " in the sense of full-grown, perfected, complete. A tremendous opening for such questioning is offered by the SDGs written to target change in every country in the UN. A recent report with foreword by Kofi Annan makes clear the need for economically powerful societies to reassess their own models:

Their inability to fight the growing social divide combined with their overuse of resources therefore shows that today's high-income countries in their current shape can no longer serve as role models for the developing world. In terms of sustainable development, all countries are now developing countries. (Kroll 2015: 5)

As transgressions of planetary boundaries not only jeopardize the survival of poorer people and places, but increasingly threaten the stability and security of wealthy populations, incentives may strengthen to learn from and with those who have been less successful at growth, and those who are refugees from uneven impacts of growth.

\section{Practices and identities entangled with growth and with efforts to change course}

Studies published in this Special Section find practices, relations and meanings relevant for degrowth in long-sustained arrangements, amid forced adaptation to unwelcome changes, and among innovations toward new visions. Not isolated as sanctuaries or imaginary utopias, they intertwine with growth-driven sociocultures in various ways. Taken together, these studies connect processes playing out in countries ranked among the highest and among the lowest in terms of GDP and ecological footprint. Long term conversations across such differences play out in Lisa Gezon's three decades of learning with Malagsy interlocutors, Ritu Verma's multiform teaching and research in Bhutan, and Jonathan DeVore's years of agroforestry labor with Brazilian squatters. These north-south conversations are complemented by researchers who engage in and write about phenomena in their own countries in the global north: Karen Foster in Canada; Eeva Berglund in Finland; Ulrich Demmer in Germany; Agata Hummel in Poland; Emma McGuirk in New Zealand; Ragnheiður Bogadóttir and Elisabeth Skarðhamar Olsen in the Faroe Islands; and Amy Cox Hall and Joshua Lockyer in the United States. Our next book project seeks to foreground writing from the global south. 
In the Faroe Islands, Ragnheiður Bogadóttir and Elisabeth Skarðhamar Olsen (2017) explore community practices and relations surrounding whaling that have endured and evolved over many centuries. They describe collaborative pilot whale harvests in which meat and blubber is shared among community members for nourishment, while no money is exchanged, nor profits generated. Detailed historical records show that the number of whales harvested each year has remained remarkably constant for centuries. Today, these Faroese traditions coexist in tension with astonishingly rapid incursions of the market economy, paid labor and global messages. Ironically, it is the long-sustained communal practices-and not the recent boom of infrastructure and commodity imports - that have become targets of attack by international environmental activists (Faroese environmentalists take a different stance). Notable outcomes of these frictions include new official regulations and certifications on harvests, raised consciousness and discussion among residents about sustaining their unique socionatural world, and more explicit commitment to ritually-embedded arrangements for governing aquatic commons and supporting community nutrition and solidarity.

This case provokes uncomfortable doubts about the universal applicability of principles that lead some well-meaning activists to condemn long-sustained communal whale harvests and to revere as morally superior means to protein the purchase of commercial products like almond milk imported from California (a commodity whose eco-footprints leave a trail connecting destructive dams, depleted aquifers and pesticide contamination; move through processing plants, packaging factories and advertising firms; and trace thousands of miles of transport fuel and emissions before arriving at newly-constructed island supermarkets).

Eric Hirsch (2017) also describes scenes in which communities long relegated as "isolated" are caught up in dynamics and debates around global growth. Seeing themselves on the frontiers of global warming, communities facing melting glaciers in Peru and rising sea levels in the Maldives embrace the cause of mitigation, but find their options to change course constrained by material conditions and power relations. In both places, the heaviest burdens of reducing emissions and rerouting everyday activities fall on the backs of those who leave the lightest carbon footprints and suffer the direst impacts of climate change. Examples from Peru, the Maldives and the Faroes reveal struggles to move forward on paths that are culturally meaningful and environmentally respectful, and offer opportunities to learn from frustrations and conflicts encountered along the way.

Residents of hundreds of ecovillages around the world strive to reduce impacts of their own lifestyles on these and other vulnerable communities. In this Section Joshua Lockyer (2017) presents quantitative analysis of material throughput in Dancing Rabbit Ecovillage to document how one group of Missouri residents substantially decreased their consumption of energy, water and key goods. Beyond the achievement of reduced material impact, these ecovillagers strive to share their visions and innovations with others through education and outreach. Ongoing conversations among and beyond ecovillages address challenges that can be thornier than material frugality and that fall outside of most sustainability science: struggles to embrace and to internalize different values, identities and relationships.

In her article on neo-monasticism and "theology of enough," Amy Cox Hall (2017) examines one intentional community's attempts to eschew consumerism and material accumulation in order to live a collective life focused on spiritual growth. Among this small Christian group in North Carolina, Cox Hall found that the most challenging and conflict-producing aspects of this collective journey did not arise from practical efforts to consume less or to manage common resources, but in attempts to rethink and live social values, personal identities and relationships not bastioned by the moral virtue of productivism.

For insight into material forms that might support such cultural transformations, LeBlanc (2017) looks to architects from postgrowth Japan and Italy who favor structures and policies that promote small messy interventions by ordinary people in public spaces. In Japan, Tahata's understanding of the powerful legal instruments that drive wasteful overbuilding provoked a commitment to transform contemporary politics, a project that would require new social consensus. So he began to design urban spaces geared to facilitate dynamics of human interaction that could generate new socialities and independence of spirit. In Italy, Ricci worked to similar ends by constructing shared spaces that foster social bonding through frequent, lightheartened convivialità (conviviality) among people of varying classes, generations and backgrounds. These projects encourage spontaneous experiences that interact to build a beautifully poor alternative to the shopping mall aesthetics and exclusionary architectonics shaping high-growth cityscapes. 
Viscerally-felt desires to experience community belonging also intermingle with more abstract commitments to environmental conservation in Helsinki, where Eeva Berglund (2017) highlights unique cultural features, including the revival of traditional working parties that were key to rural livelihoods and community solidarity in decades past. The Finnish term and practice talkoot are familiar to most people in a nostalgic way; now they are re-emerging in private and public life alongside environmental concerns articulated in sophisticated scientific language, another notable feature of Helsinki discourse. While the government used talkoot to soften austerity measures in 2015, parallel practices of communal labor are flourishing in urban neighborhood associations, coops and voluntary organizations and events.

The potential of non-expansionist cultural forms and features that may be immanent-albeit underrecognized - in high-growth societies is evident in the meteoric rise of networks for sharing rides, homes, tools, skills, food, and favors (some of which generate profit, while others eschew it), and in the surging popularity of doing-it-yourself (Berglund 2017; McGuirk 2017; Smith-Nonini 2016). We have much more to learn from modes of human organization grounded in mutual aid, reciprocity, collaboration and inclusion that are woven into the fabric of everyday life in wealthy societies (White and Williams 2014).

Such modes play different roles in the fabric of societies that have never enjoyed much growth. In her article about livelihoods in urban Madagascar, Gezon (2017) examines patterns of decision-making that defy the rationale of Homo economicus and challenge distinctions between utilitarian and anti-utilitarian practice. In contrast to advocates of economic development who deride the widespread habit of chewing khat as a waste of time and resources, inimical to growth, Gezon understands that long hours spent chewing khat with friends and associates may be integral to making a living, a project that invokes a web of material desires, cultural meanings and reciprocal social obligations not reducible to cash income. Her findings suggest that paths to more sustainable lifeways do not need to depend solely on the invention of new imaginaries, but can also value and leverage social practices and cognitive orientations that have long existed, but that have been disdained as irrational or immoral, or perhaps fallen below the radar altogether, in mainstream economic analysis. One promising outcome of this awareness is predicted by economist Richard Thaler (2000: 236): "The species populating economics models will become more heterogeneous."

Practices described here suggest that good living in futures not centered in growth will require different kinds of relationships between citizens and the spaces they construct and inhabit: new political ecologies. Taken together, the studies highlight divides among diversely located and conceptualized worldmaking projects, and also seek dialogue among them on paths toward positive change in scientific and social values and practices.

\section{The paradox of much information, and not enough change}

Here is the paradox: throughout the past half century, rigorous scientific research has shown extensive evidence of negative environmental consequences of material growth, matched more recently by a deluge of data on unevenly detrimental social costs of economic growth. Those findings have been widely disseminated in scientific publications and also in popular books and films calling for change based on rational application of scientific knowledge (Carson 1962; Gore 2007; Ellis 2010; Lappé 1971; Leopold 1949; Piketty and Goldhammer 2015; Rockström et al. 2009; Schumacher 1973; Wilkinson and Pickett 2011). Meanwhile, organizations and policy makers have convened thousands of conferences, signed scores of conventions, and funded billions of dollars of programs in attempts to mitigate undesirable social and environmental outcomes that have accompanied the unprecedented boom of global growth. Yet, the mass of matter and energy transformed and degraded by human economies continues to expand by the minute, while nearly every instance of government and business continues to promise and to prioritize more economic growth.

Attempts to understand and respond to this paradox are taking wildly diverse forms, which is a good thing, since it will certainly take a multitude. Such heterodoxy is also a tricky thing, since it is not known which approach will work to advance what ends, or which effort will jeopardize other advances; it is not even clear how and with what criteria those assessments can be made. Some of the practical actions advanced in relation to degrowth are: agroecology, back-to-the-landers, basic and maximum income, community currencies, co-operatives, debt audit, digital commons, ecovillages, job guarantees, social enterprises, sharing 
economies, timebanks, transition towns, urban gardening and work sharing (D'Alisa, Demaria and Kallis, 2014; Sekulova et al. 2013). Policy and legislative initiatives proposed on various levels address socioenvironmental costs and impacts that have been externalized from market mechanisms, as well as changes needed within those mechanisms. It seems that the easiest course might be to simply take a break from push, push, pushing increased production and consumption via advertisement, pricing, subsidies, taxing, trade pacts, zoning and innumerable other measures. Yet, efforts on all these fronts meet resistance of formidable strength and bewildering forms.

For the purpose of bending quantitative trends away from growth, many initiatives put into practice so far appear relatively impotent, at least in the short term. One person's endeavor to consume less and share more is a drop in the tidal wave of growth fueled by zealous intercourse between financial capital, extraction and productive enterprise. It seems quite possible that millions of people could embrace voluntary simplicity, vegetarianism, recycling, downshifting (Schor 1999) or ecovillage living (Lockyer and Veteto 2013) without making a dent in the ongoing expansion of global societal metabolism and GDP. The two final sections, then, explore dynamics of culture and power that enhance or constrain the transformative potential of these and other modest actions.

\section{How can tiny efforts add up to a great transition?}

What can enable local initiatives to catalyze the kind of changes necessary for equitable downscaling of global production and consumption that enhances human and ecological well-being? Leading scholars have rightly identified the need to establish supportive structural conditions by changing economic institutions and political processes in national and international arenas (Boillat et al. 2012; Sekulova et al. 2013; Daly 1996; Spratt et al. 2009). This section explores complementary strategies involving new modes for producing knowledge and value; the following one explores modes for (re)producing socialized humans and relationships.

Inspired by Karl Polanyi's (1944) use of "The Great Transformation" to characterize the violent upheaval of lifeways and productive systems with the emergence of industrial market economy in $18^{\text {th }}-19^{\text {th }}$ century England, the term "Great Transition" is used to visualize a very different historic shift for the $21^{\text {st }}$ century by actors ranging from British economist Kenneth Boulding (1964) to the Stockholm Environment Institute (Raskin et al. 2002), Bhutan Prime Minister Jigme Thinley (2012), the New Economics Foundation (Spratt et al. 2009), and founders of the Italian Degrowth Association (Bonaiuti 2014). Seeking common ground, Escobar (2015: 452) writes: "Transition discourses take as their point of departure the notion that the contemporary ecological and social crises are inseparable from the model of social life that has become dominant over the past few centuries."

Wikipedia's entry on Great Transition contrasts two variants: eco-communalism and new sustainability paradigm.

Eco-communalism, a highly localist vision of a lifestyle that turns to non-material dimensions of fulfillment (the quality of life, the quality of human solidarity, and the quality of the earth), is favored by some environmental subcultures, particularly the anti-globalization movement. New Sustainability Paradigm, by contrast, sees globalization not as a threat to be resisted, but as an opportunity for forging a new category of consciousness - a global citizenship that understands humanity's place in the web of life and its link to the fate of the earth. ${ }^{9}$

Here I urge attention away from contrasts that separate these variants and toward dynamics that connect them. Global moves like the UN SDGs, the People and the planet report, and the Intergovernmental Panel on Climate Change interact with national policies such as Bhutan's Gross National Happiness, Germany's energy transition, and Maldives' zero carbon commitment. These, in turn, evolve via mutual

\footnotetext{
${ }^{9}$ Accessed 9 August 2016, text subject to change https://en.wikipedia.org/wiki/Great Transition.
} 
influence with place-based phenomena including transition towns, religious movements, timebanking networks, and neighborhood spaces.

What happens if we shift ambition away from determining which of these is the right answer, and away from empowering the best solution, toward building potential for synergy among many kinds of answers and solutions playing out differently across spaces, scales and social groups? Among other challenges, the wager that an unknown number of initiatives will interact positively in unforeseeable synergies will need to be bastioned by emerging sciences of uncertainty and complexity. Amid growing conviction that transition toward other worlds cannot be driven by one grand theory, Shiv Visvanathan (1997) and Boaventura de Sousa Santos (2007) call for pursuit of "cognitive justice" through epistemic changes that dignify diverse paradigms, and via institutions that foment dialogue among what are now deemed incommensurable ways of knowing.

The global empowerment of one scientific culture has led to acute contradictions: "Despite, and because of, great acceleration of scientific knowledge and technology over the last few hundred years, human-nature systems are in danger of collapse" (Parra and Walsh 2016: 229). Recent attention to modes of knowledge production less centered in colonial and capitalist paradigms is opening epistemological horizons (e.g., Gibson-Graham 1996, 2008). Burke and Shear (2014: 130) argue that, in times of socioecological crises, it is insufficient for intellectuals to critique problematic structures; they must also write about heterodox practices and systems, help develop and disseminate visions supporting them, and engage actively in co-constructing alternatives. In this Section Emma McGuirk (2017) describes her endeavors to enact all of the above amid participatory action research with timebank participants in New Zealand. Similarly, Lockyer (2017) recounts how he asked a community of ecovillagers "how can my skills, knowledge and methods serve your vision and needs?" and then gradually co-created a research project addressing residents' desires to assess and enhance progress toward goals of living ecologically-sustainable, socially-rewarding and personally-fulfilling lifestyles.

Some scholars find opportunities to support change by operating within, and also stepping outside of, received epistemic and institutional boundaries. In this Section Ulrich Demmer and Agata Hummel (2017) write about Demmer's experience as "translator," moving ideas among a Transition Town in Heidelberg, university classes in Munich, and an eco-community in Barcelona. They also reflect on Hummel's practice of "weaving" together diverse actors and initiatives in her work co-hosting a degrowth-related internet platform and varied live encounters, such as a visit by members of a Swiss Community Supported Agriculture group that motivated the formation of Poland's first CSA. In serving as conduits that connect different conversations, these and other researchers are learning about—and also consciously contributing to-efforts to construct various kinds of anti-hierarchical, self-organized and ethical social organisms. Dianne Rocheleau characterizes this wave of activist-research as a "way to harness practical political ecology, and to demonstrate that many other worlds are possible and practical" (2007: 723).

Controversies incited by these forays into ontological politics of science evolve around claims that not only activist research, but also conventional science, is actively involved in the making of what is studied, and that Western science is one type of cultural knowledge and performance among others (practical, spiritual, ritual, etc.) through which people everywhere participate in the politics of (re)producing socioecologies. It is one thing to study ethnoscience by investigating how various others perceive and categorize the world; it is quite another to argue that all science is ethnoscience, that no human knowledge system fully transcends its cultural roots, nor its ethnocentrism.

Recognition that monetary systems too are shaped by culture and power opens possibilities to question — and even to change — that sacred object called money. Alf Hornborg's article in this Section (2017) answers the question of "How to turn an ocean liner?" with a multi-scale proposal aimed at shifting the regimes through which communities establish and exchange value. Arguing that cultural artifacts play a crucial role in organizing societies, Hornborg pays close attention to the artifact of money. He proposes to complement globally-circulating general-purpose money with a move in which each country establishes a currency for use in geographically-restricted zones, distributed to all residents as basic income. Hornborg argues that distinction between these separate monetary spheres would help diverse local systems of 
production and exchange to adapt and thrive, thanks to greater insulation from deleterious effects of global financial speculation. Importantly, the process of constructing and participating in institutions and daily practices around local money would influence the place-based (re)production of deeply felt valuations.

The production of monetary and other types of value is intertwined with the production of knowledge in institutions of higher learning, which have increasingly sought to raise revenue and ranking via quantitative increases in scientific grants, outcomes and publications. Temporal acceleration of intellectual production cycles has led to resistance against isolating effects, embodied work conditions, and narrow results engendered in the process:

Good scholarship requires time: time to think, write, read, research, analyze, edit, and collaborate. High quality instruction and service also require time: time to engage, innovate, experiment, organize, evaluate, and inspire. This kind of slow work both defies and is threatened by the myriad demands on our time as academic laborers. (Mountz et al. 2015: 3)

These and other scholars call for institutions that promote working with care, while also caring for ourselves and others, in modes of intellectual production that foster deep reflexive thought, engaged research, and joy in writing and teaching. The slow science manifesto written in 2010 by members of The Slow Science Academy based in Berlin, addresses issues relevant to our central paradox, among them the dissociation of biophysical and social sciences from humanist reflections on meaning and value: "We do need time to think. We do need time to digest. We do need time to misunderstand each other, especially when fostering lost dialogue between humanities and natural sciences." ${ }^{10}$

Recognition that the concepts and methods that shape scientific results (and that influence studied phenomena along the way) are never free from culture nor innocent of power, raises questions about how priorities and mythologies of growth have shaped the historical development of knowledge. Whereas scientific theory and practice have been shaken in recent decades by revelations of androcentric and ethnocentric biases (Collins 1986; Dahlberg 1981; Haraway 1989; Harding 1991, 2006, 2011; Seth 2009), growth-centric biases are just beginning to draw attention from scholars seeking paradigms that better enable positive change (e.g. Cattaneo et al. 2012).

\section{How do we humans change?}

In his encyclical letter On care for our common home, Pope Francis (2015) exhorts: "Many things have to change course, but it is we human beings above all who need to change." So we conclude by turning to the heart of change: systems of culture and power through which human beings and socioecological worlds are (re)produced, sustained and adapted. ${ }^{11}$ This final section advances a cluster of concepts (mode of production, habit, embodiment and dwelling) that highlight mutually-influencing dynamics among sociocultural systems and biophysical processes, and demonstrates those dynamics through tangible examples from half a dozen countries. Perplexed by widespread resistance to the possibility of changing certain aspects of ourselves and our worlds, I expose popular myths of biological determination that serve to constrain abilities to think beyond the status quo, then conclude by celebrating those unique biological characteristics that enable humans to imagine, communicate and construct an endless variety of socioecological worlds.

New conceptualizations of mode of production pay attention not only to how humans manufacture food, shelter, clothing (and profit); but also to how we co-produce biophysical landscapes, together with regimes of production, knowledge and governance. The most amazing thing that we humans produce is ourselves: differentiated human bodies socialized with skills, visions and desires, including appetites for consumption. This way of thinking about mode of production connects with three approaches developed

\footnotetext{
${ }^{10}$ slow-science.org accessed 25 October 2016.

11 This section draws ideas and passages from Paulson 2014, and from a 2016 lecture available at http://www.resilience.org/stories/2016-09-23/capitalism-and-de-growth
} 
successively in the field of political ecology. The first analyzes political economic factors in environmental degradation; the second explores epistemological processes through which cultural, scientific and political concepts and discourses impact human-environment relations; and the third raises ontological questions about processes through which myriad socioecological worlds are produced and reproduced (Escobar 2010: 92).

Habitual participation in urban cooperatives, whaling traditions, community gardens, local currencies, timebanks, khat chewing, transition towns, religious communities and ecovillages, among others, leads some people to adapt lifeways that use less material and energy. Loss of employment, economic recession, and collapse of industries and ecosystems sometimes lead to similar outcomes. Putting aside calculations of the short-term impacts that such participation may (or may not) have on ecological footprints and market activity, we shift attention to the transformative role it plays in the continual becoming of participants as social actors and moral beings, and in the practices and relations that co-produce new generations of humans and future socioecosystems.

In this Section, Karen Foster (2017) probes the power of a culturally embedded work ethic to produce people who face difficulty acting, and even being, outside of a productivist paradigm. Workers she interviewed in Atlantic Canada, like many in other contexts, have learned to be decent people according to moral codes in which virtuous behavior is epitomized by long hours of hard work in contrast to the dissolute laziness of leisure. The primacy of paid work in constituting identity and dignity constrains laborers' ability to question economic systems in which they participate. However, in shrinking rural economies where jobs (let alone long hours) can be elusive, Foster searches for clues about how communities might reorient toward perceiving paid work as one means to moral ends, rather than an end in itself, or a definition of self.

In several Latin American contexts, I have been seeking to understand men's participation in economic practices and relations that seem to exploit their own human resources and undermine their socioecosystems (Paulson 2013, 2015). Two features of prevailing gender norms stand out among cases studied. First is a symbolic binary that associates masculinity with paid "productive work," in contrast to unpaid "reproductive work" construed as feminine and as inferior. Second are constructions of subordinate masculinities in which manliness is measured by one's capacity to perform brutally hard labor in uncomfortable conditions, and virility is displayed by taking risks, and by exercising and enduring violence. These norms did not come from the Garden of Eden. Over generations, different kinds of policies and propaganda have influenced the adaptation of gender and kinship systems to produce bodies and identities that serve the evolving growth machine. The fruit of these historical processes is evident today in the millions of low-paid men who perform dangerous and painful work necessary for the expansion of industries that degrade local environments and exacerbate global climate change: mining, logging, petroleum and agroindustry.

Labor markets that offer more wholesome opportunities might support positive change; however, economic institutions do not function independently of relations of power and difference, nor of identity and desire. Efforts to turn away from the wave of extractivism ravaging Latin American environments will require changes in the systems that (re)produce human resources in the form of tough men suitable for use in toxic and violent environments. To be sustainable, those changes must also address consequences of a different kind of gendered policies and programs that have worked since 1980 to incorporate 70 million women into Latin America's paid labor force, while doing little to buttress the reproductive labor necessary to sustain families and societies (Chioda 2016). During interviews carried out this year in Ecuador and Mexico, dozens of men told me about physical and emotional hardships that they (and their fathers before them) had experienced in efforts to meet expectations of manhood. Some also described efforts through which they are trying to change norms that have constrained their own horizons. By adapting their personal practices and interactions, and by adjusting the expectations they communicate for others, some working men are consciously trying to raise sons and daughters capable of following —or even forging — a wider range of paths. 
These observations shed light on the puzzle of why scientific facts and arguments about negative impacts of growth have provoked so little consequential change. By appealing to individual reason, scientists and policy-makers disregard systems of culture and power through which identities and values are viscerally incorporated. Our studies suggest that individuals' ability and willingness to moderate their involvement in expansionist practices and institutions involves more than rational decision-making; it may be nurtured-or constrained - through other kinds of human experience, particularly bodily action and interaction.

The dwelling of living organisms in landscapes and taskscapes is theorized by Tim Ingold (2000, 2011) as a process of mutual becoming in which meanings are not simply assigned to the world by human cognition, but continually worked out via corporal practices that build "muscular consciousness." These embodied histories guide the way individuals and communities sense and orient themselves in relation to their environments and each other, influencing habitual biosocial interactions that, through time, co-construct people and landscapes. Some modes of dwelling in today's world produce subjectivities that repress acknowledgement of and resist response to certain signs of degradation and inequity. As Eriksen and Schober (2016: 3) argue, "The concept of habit-in the double meaning of the word of learned pattern and addiction - may be a crucial component for understanding the interplay between social, political, economic, and cultural factors motivating our era of denial." Modes of dwelling also cultivate sensitivities. In rural Brazil, DeVore (2017) describes daily practices in which individuals nurture and protect specific springs and trees, practices that - over time- contribute to the (re)production of shared water sources and forests, and the (re)production of relations among humans and with other nature. Lockyer (2017) describes commoning practices through which dozens of people have been working together on 280 acres (113 ha) of communal land to continually build Dancing Rabbit ecovillage; in the process, they have produced different forms of physicality and subjectivity, expressed today in relationships and decision-making more sensitive to impacts on other people and other nature.

Via muscular consciousness and neuroplasticity we humans continually produce ourselves and our new generations. Large and small adjustments to habits of thought, action and interaction work in mysterious ways toward institutional and paradigmatic change. Testimonies recorded by Emma McGuirk (2017) among timebank members in New Zealand show that habitual participation in what seem like menial commonplace transactions has led to deeper transformation. Notable outcomes for individual timebankers include increased desire for and energy invested in local networks of solidarity and friendship. Via biophysical and psychosocial habits developed through timebanking, people not only adapt themselves, they also create and experiment with small-scale networks that are enjoyable to use, while contributing to prefigurative modes that lay foundations for future world-making.

In the short run, then, my voluntary shift from a jet-setting lifestyle toward lower-impact living has little chance of slowing the global growth machine. However, my new habits will definitely alter the ways in which I become human each day forward, thereby influencing environments and processes through which family members, students, colleagues and others around me continually become human. Producing new kinds of people and relationships is fundamental to any cultural transformation and great transition.

It is dangerously ingenuous, however, to think about change as merely a function of individual volition. Material conditions-embodied and environmental—variously circumscribe each of our abilities to change course, as do worldviews, assumptions and ideologies. Life stories in rural Brazil draw attention to conditions that enable or constrain people's capacities to walk away from exploitative relations instrumental to economic expansion. DeVore (2014: 508-511) recounts the narrative of three brothers who, as teenagers in the 1960s, went to work clearing forest on a rubber plantation owned by Firestone. Upon discovering the dreadful conditions and irregular payment, the three decided to literally walk away; taking dry goods from the company store in lieu of wages, they hiked 40 kilometers to find their father on another plantation. DeVore (2014: 331-336) also describes a contrasting case: an aging landless man with one foot disfigured by a work accident, who lamented that "his need to rest his body—so that he could heal— and his need to continue working—so that he could eat—warred with one another." Bodily constraints and limited 
relationships compelled this man to continue living and working under conditions set by employers, conditions in which his daily becoming led toward physical deterioration and social alienation.

Such dynamics of power change the question of "how do we humans change?" to "how do we change humans?" In countries around the world, longitudinal data show abrupt upswings in behavioral trends ranging from fuel consumption to obesity and use of credit, signaling that some powerful forces have been at work changing modes of being human, and changing them at precipitous speed. With US data from late $20^{\text {th }}$ century, economist Juliet Schor $(1993,1999)$ charts remarkably steep average increases in hours worked for pay, in material goods consumed, and in personal debt. She also points to legislation, policies and advertisements that interacted to impel adoption of personal habits that would be instrumental to the exponential growth curve emblematic of these times.

Despite astounding transformations in human practice and perception in recent decades, actors who are privileged by today's status quo - and even many who are exploited or marginalized — protest that it is neither ethical nor feasible to try to change human behavior or attitudes: "You're never going to convince people to produce and consume less!" Degrowth is vehemently denounced as ecofascism: ideologicallydriven imposition that would force unwilling victims to sacrifice their God-given freedoms and to betray innate self-interests. Growth, in contrast, is perceived as apolitical and impartial; modern markets, in particular, appear as timeless mechanisms through which all humans freely organize livelihoods and establish value. Polanyi (1944) showed they are anything but. The commodification of labor and nature, together with the colonization of human habits and worldviews by market-relations and money-value, are historical exceptions brutally imposed in 18th and 19th century England by efforts to "mold human nature" for industrial growth. Moving to late 20th century, David Harvey (2007) and others have exposed the formidable political incursions enacted to force expansion of "free" market relations-together with characteristic forms of unequal exchange-into the most isolated parts of the world and the most intimate realms of human intercourse.

A stubborn blindness to these and other historical facts is enabled by certain architectural features of Western language, science and philosophy. Hierarchical binaries of white over non-white, man over woman, human over other nature are engraved in the world in ways that make it difficult to question the mechanisms of unequal exchange and accumulation built into current markets. As the nature-culture binary classifies thinking humans as superior to instinct-driven beasts, it also suppresses attempts to change certain aspects of human life by cementing them as unassailable "natural instincts." Today, the conviction that human biology is responsible for an insatiable drive to increase production and consumption is fostered by powerful cultural and scientific narratives. Featured myths include the innately rational Homo economicus maximizing utility for individual gain; an inherent human propensity to truck and barter avowed by Adam Smith; and that "selfish gene" that makes each of us crave control over resources and strive to take more than our share, condemning to tragedy any attempts at commons management.

Even climate change is portrayed as a result of human evolution! Teleological narratives surrounding the Anthropocene are encouraged by scholars such as Steffen, Crutzen and McNeill (2007: 614) who write: "the first use of fire by our bipedal ancestors, belonging to the genus Homo erectus, occurred a couple of million years ago." And "The mastery of fire by our ancestors provided humankind with a powerful monopolistic tool unavailable to other species, that put us firmly on the long path towards the Anthropocene" (for astute critique, see Malm and Hornborg 2014: 65).

Antonio Gramsci (1971) taught us to beware the power of cultural constructs that make the status quo appear natural and inevitable. He also noted that historical crises can destabilize that power, opening transformative possibilities. To debunk laissez faire myths impervious to factual contestation, Erik Swyngedouw (2015) and others call for (re)politicization of economic and ecological conversations. Horizons for change can also be opened by learning from diverse socionatural worlds. Against contemporary beliefs that human survival depends on growth, archeological and ethnographic evidence demonstrates that diverse hunter-gatherer-fisher populations characterized by extremely low societal metabolism and little or no market activity have thrived and adapted throughout all 200,000 years of modern human life. Even in the 
present age, meticulous measurements have documented remarkably low societal metabolism of groups ranging from Andaman Islanders (Singh and Haas 2012) to !Kung San (Lee 1968, 1979). ${ }^{12}$

If Homo sapiens is hard wired for growth, why did per capita ecological footprints increase so late in the game? And so unevenly across human populations? Evidence points to gradual expansion among some groups starting 10,000 years ago with the emergence of agriculture and cities, followed by steeper increases beginning several hundred years ago with European colonial expansion and industrialization. It is not until the twentieth century, however, that a supercharged boom of material and economic growth combined with exponential increase in world population to provoke a tectonic shift in which human activities "rapidly changed from merely influencing the global environment in some ways to dominating it in many ways" (Steffen et al. 2007: 614). Scientists assessing climatic, biological and geochemical signatures of human activity in sediments and ice cores have come to consensus on marking a new epoch, beginning in the mid20th century, as "the Anthropocene" (Waters et al. 2016).

Putting these extraordinary recent changes into deeper historical and broader cultural context reveals the absurdity of claims that ancient evolutionary traits inexorably led Homo sapiens to destroy earth systems. It also challenges the misleading message-as widespread as it is dangerous - that this new era was provoked by humanity as a whole (the Anthropos), rather than by one group acting in and through a historically specific system of culture and power. Scholars fighting for a more accurate characterization insist that the era be called the "Eurocene" or the "Capitalocene" (e.g. Moore 2016).

Cross-cultural and historical studies published in this Section and elsewhere reveal glimpses of worlds not driven by the kind of expansionism that has recently impacted the earth's geology, oceans and atmosphere. Our appreciation of these low-impact lifeways is sometimes reproached as promoting a devolution to so-called "primitive" or "third world" conditions. Looking forward, however, awareness of many possible modes of existence-with myriad sources of richness and pleasure-widens horizons for building unprecedented futures. It does so by liberating us from the fiction that human behaviors currently instrumental to growth are biologically determined universals.

However, there is something about human biology that is relevant to this conversation. Species interacting in the earth's ecosystems display an amazing array of characteristics evolved to meet their needs and to assure their descendants' survival: spotted salamanders use solar power, Atlantic wolf fish manufacture antifreeze, and African dung beetles navigate by the Milky Way; cacti grow spines to defend their juicy stems, while nettles puncture predators to inject poison into tiny wounds. Compared to other creatures, individual humans do not shine as particularly strong, quick or tough, not to mention spikey or poisonous.

What is unique to Homo sapiens is a biophysical capacity for symbolic thought and communication that enables groups of humans to collaboratively develop systems of culture and power that survive the individual organism, and that shape the production of new generations of humans, their habits and their habitats. These uniquely human systems take the form of languages, religions, economies, sciences, kinship and gender systems, among others. Communities around the world are already managing and adapting these most fundamental common resources in ways that can support equitable and pleasurable degrowth.

\footnotetext{
12 Also see relevant (pre)historical studies in publications like Ecology and power (Hornborg, Clark and Hermele 2012) and Stone age economics (Sahlins 1972).
} 


\section{Degrowth, culture and power, edited by Lisa L. Gezon and Susan Paulson}

1. Robin M. LeBlanc. Designing a beautifully poor public: postgrowth community in Italy and Japan

2. Eric Hirsch. The unit of resilience: unbeckoned degrowth and politics of (post)development in Peru and the Maldives

3. Ritu Verma. Gross National Happiness in Bhutan: meaning, measure and degrowth in a living development alternative

4. Jonathan Otto. Finding common ground: exploring synergies between degrowth and environmental justice in Chiapas, Mexico

5. Ragnheiður Bogadóttir and Elisabeth Skarðhamar Olsen. Making degrowth locally meaningful: the case of the Faroese grindadráp

6. Joshua Lockyer. Community, commons, and degrowth at Dancing Rabbit Ecovillage

7. Amy Cox Hall. Neo-monastics in North Carolina, de-growth and a theology of enough

8. Eeva Berglund. Steering clear of politics: local virtues in Helsinki's design activism

9. Lisa L. Gezon. Beyond (anti)utilitarianism: khat and alternatives to growth in northern Madagascar

10. Emma McGuirk. Timebanking in New Zealand as a prefigurative strategy within a wider degrowth movement

11. Ulrich Demmer and Agata Hummel. Degrowth, anthropology, and activist research: the ontological politics of science

12. Alf Hornborg. How to turn an ocean liner: a proposal for voluntary degrowth by redesigning money for sustainability, justice, and resilience

13. Karen Foster. Work ethic and degrowth in a changing Atlantic Canada

14. Jonathan DeVore. Trees and springs as social property: a perspective on degrowth and redistributive democracy from a Brazilian squatter community

\section{References}

Asafu-Adjaye, J., L. Blomquist, S. Brand, B.W. Brook, R. Defries, E. Ellis, C. Foreman, D. Keith, M. Lewis, M. Lynas, T. Nordhaus, R. Pielke, R. Pritzker, J. Roy, M. Sagoff, M. Shellenberger, R. Stone and P. Teague. 2015. An ecomodernist manifesto. www.ecomodernism.org/

Bebbington, A.J., S. Hickey and D.C. Mitlin (eds.), 2008. Can NGOs make a difference? The challenge of development alternatives. London: Zed.

Beling, A.E., F. Gomez, and J. Vanhulst. 2014. Del Sumak Kawsay al Buen vivir: filosofía andina como base para una racionalidad ambiental moderna. In C.M. Gómez (ed.) La religión en la sociedad postsecular. Transformación y relocalización de lo religioso en la modernidad tardía. Bogotá, Colombia: Universidad del Rosario-Centro de Estudios Teológicos y de las Religiones (CETRE).

Bell, K. 2016. Green economy or living well? Assessing divergent paradigms for equitable eco-social transition in South Korea and Bolivia. Journal of Political Ecology 23: 71-92.

Berglund, E. 2017. Steering clear of politics: local virtues in Helsinki's design activism. Journal of Political Ecology 24: 566-581.

Blaikie, P.M. 1985. The political economy of soil erosion in developing countries. London: Longman.

Boff, L. 1995. Ecología: grito da terra, grito dos pobres. São Paulo: Editora Ática.

Boff, L. 1997. Cry of the earth, cry of the poor. Maryknoll, New York: Orbis Books. 
Bogadóttir, R. and E. Skarðhamar Olsen. 2017. Making degrowth locally meaningful: the case of the Faroese grindadráp. Journal of Political Ecology 24: 504-518.

Boillat, S., J.F. Gerber and F.R. Funes-Monzote. 2012. What economic democracy for degrowth? Some comments on the contribution of socialist models and Cuban agroecology. Futures 44(6): 600-607.

Bonaiuti, M. 2012. Growth and democracy: trade-offs and paradoxes. Futures 44: 524-534.

Bonaiuti, M. 2014. The great transition. London: Routledge.

Borowy, I. 2013. Degrowth and public health in Cuba: lessons from the past? Journal of Cleaner Production 38: $17-26$.

Boulding, K.E. 1964. The meaning of the $20^{\text {th }}$ century - the great transition. New York: Harper Colophon.

Broder, J.M. 2011. Emissions fell in 2009, showing impact of recession. The New York Times. [accessed August 12 2016].

Brown, M.T. (ed.). 2001. Emergy synthesis 1: theory and applications of the emergy methodology. Proceedings of the 1st Biennial Emergy Conference. Center for Environmental Policy, University of Florida, Gainesville.

Burke, B.J. and B.W. Shear. 2014. Introduction: engaged scholarship for non-capitalist political ecologies. Journal of Political Ecology 21: 127-144.

Carson, R., 1962. Silent spring. New York: Houghton Mifflin Company.

Cattaneo, C., G. D'Alisa, G. Kallis and C. Zografos. 2012. Degrowth futures and democracy. Futures 44(6): 515-523.

Chioda, L. 2016. Work and family: Latin American and Caribbean women in search of a new balance. Washington, DC: World Bank.

Collins, P.H. 1986. Learning from the outsider within: the sociological significance of black feminist thought. Social Problems 33: s14-s32.

Cowen, M., and R. Shenton. 1998. Agrarian doctrines of development: part 1. Journal of Peasant Studies 25: 49-76.

Cox Hall, A. 2017. Neo-monastics in North Carolina, de-growth and a theology of enough. Journal of Political Ecology 24: 543-565.

D'Alisa G., F. Demaria and G. Kallis (eds.). 2014. Degrowth: a vocabulary for a new era. London: Routledge.

Dahlberg, F. (ed.). 1981. Woman the gatherer. New Haven, CT: Yale University Press.

Daly, H.E. 1996. Beyond growth: the economics of sustainable development. Boston: Beacon Press.

Dammann, E. 1972. Fremtiden i våre hender. Oslo: Gyldendal.

Dammann, E. 1979. The future in our hands. Oxford: Pergamon Press.

Demmer, U. and A. Hummel. 2017. Degrowth, anthropology, and activist research: the ontological politics of science. Journal of Political Ecology 24: 610-622.

DeVore, J. 2014. Cultivating hope: struggles for land, equality, and recognition in the cacao lands of southern Bahia, Brazil. Ph.D. dissertation. Ann Arbor, MI: University of Michigan.

DeVore, J. 2015. The landless invading the landless: participation, coercion, and agrarian social movements in the cacao lands of southern Bahia, Brazil. The Journal of Peasant Studies 42(6):1201-1223.

DeVore, J. 2017. Trees and springs as social property: A perspective on degrowth and redistributive democracy from a Brazilian squatter community. Journal of Political Ecology 24: 644-666.

Ellis, R. 2010. The empty ocean. Washington: Island Press.

Eriksen, T.H. and E. Schober. 2016. Economies of growth or ecologies of survival? Ethnos in press.

Escobar, A. 1995. Encountering development: the making and unmaking of the third world. Princeton: Princeton University Press. 
Escobar, A. 2009. Other worlds are (already) possible: self-organization, complexity, and post-capitalist cultures. In J. Sen and P. Waterman (eds.) The World Social Forum: challenging empires. Montreal: Black Rose Books.

Escobar, A. 2010. Postconstructivist political ecologies. In M.R. Redclift and G. Woodgate (eds.) International handbook of environmental sociology. Cheltenham: Edward Elgar.

Escobar, A. 2015. Degrowth, postdevelopment, and transitions: a preliminary conversation. Sustainability Science 10(3): 451-462.

Ferguson, J. 1994. The anti-politics machine: development, depoliticization, and bureaucratic power in Lesotho. Minneapolis: University of Minnesota Press.

Fischer-Kowalski, M. and W. Hüttler. 1998. Society's metabolism: the intellectual history of Materials Flow Analysis, Part II, 1970-1998. Journal of Industrial Ecology 2(4): 107-136.

Fletcher, R. 2016. Decoupling: a dangerous fantasy. [accessed August 12 2016].

Foster, K. 2017. Work ethic and degrowth in a changing Atlantic Canada. Journal of Political Ecology 24: 633-643.

Francis, P. 2015. Laudato Si' On care for our common home. Vatican City: Encyclical Letter, Librería Editrice Vaticana. [accessed August 13, 2016].

Funtowicz, S.O. and J.R. Ravetz. 1994. Uncertainty, complexity and post-normal science. Environmental Toxicology and Chemistry 13(12): 1881-1885.

Georgescu-Roegen, N. 1971. The entropy law and the economic process. Cambridge: Harvard University Press.

Gezon, L.L. 2017. Beyond (anti)utilitarianism: khat and alternatives to growth in northern Madagascar. Journal of Political Ecology 24: 582-594.

Gibson-Graham, J.K. 1996. The end of capitalism (as we knew it): a feminist critique of political economy. Minneapolis: University of Minnesota Press.

Gibson-Graham, J.K. 2008. Diverse economies: performative practices for 'other worlds.' Progress in Human Geography 32(5): 613-632.

Global Footprint Network. 2014. Global footprint network annual report [accessed August 16, 2016]. http://www.footprintnetwork.org/documents/GFN_AR_2014_final.pdf

Gore, A. 2007. An inconvenient truth: the planetary emergency of global warming and what we can do about it. Emmaus, Pennsylvania: Rodale.

Gorz, A. 1980. Ecology and freedom. In A. Gorz. Ecology as politics. Québec: Black Rose Books.

Gramsci, A. 1971 [1928-1935]. Selections from the prison notebooks of Antonio Gramsci. New York: International Publishers.

Gudynas, E. 2011. Buen Vivir: today's tomorrow. Development 54(4): 441-447.

Haberl, H., M. Fischer-Kowalski, F. Krausmann, H. Weisz and V. Winiwarter. 2004. Progress towards sustainability? What the conceptual framework of material and energy flow accounting (MEFA) can offer. Land Use Policy 21(3): 199-213. Academia

Haberl, H., M. Fischer-Kowalski, F. Krausmann, J. Martinez-Alier, and V. Winiwarter. 2011. A sociometabolic transition towards sustainability? Challenges for another great transformation. Sustainable Development 19(1): 1-14. Researchgate

Haberl, H., K.H. Erb, F. Krausmann, V. Gaube, A. Bondeau, C. Plutzar, S. Gingrich, W. Lucht and M. Fischer-Kowalski. 2011. Quantifying and mapping the human appropriation of net primary production in earth's terrestrial ecosystems. Proceedings of the National Academy of Sciences 104(31): 1294212947.

Haraway, D. 1989. Primate visions: gender, race, and nature in the world of modern science. New York: Routledge.

Harding, S. 1991. Whose science? Whose knowledge? Thinking from women's lives. Ithaca, NY: Cornell University Press. 
Harding, S. 2006. Science and social inequality: feminist and postcolonial issues. Chicago: University of Illinois Press.

Harding, S. (ed.). 2011. The postcolonial science and technology studies reader. Durham: Duke University Press.

Harvey, D. 2007. A brief history of neoliberalism. Oxford: Oxford University Press.

Hirsch, E. 2017. The unit of resilience: unbeckoned degrowth and politics of (post)development in Peru and the Maldives. Journal of Political Ecology 24: 462-475.

Hornborg, A. 2017. How to turn an ocean liner: proposal for voluntary degrowth by redesigning money for sustainability, justice, and resilience. Journal of Political Ecology 24: 623-632.

Hornborg, A., B. Clark and K. Hermele. 2012. Ecology and power: struggles over land and material resources in the past, present and future. New York: Routledge.

Hornborg, A. and J. Martinez-Alier. 2016. Ecologically unequal exchange and ecological debt. Special Section. Journal of Political Ecology 23: 328-491.

Hornborg, A., J.R. McNeill and J.M. Alier. 2007. Rethinking environmental history: world-system history and global environmental change. Lanham: Altamira Press.

Ingold, T. 2000. The perception of the environment: essays on livelihood, dwelling and skill. London: Routledge.

Ingold, T. 2011. Being alive: essays on movement, knowledge and description. London: Routledge.

IPCC. 2013. Fifth assessment report (AR5) of the United Nations Intergovernmental Panel on Climate Change. Geneva: IPCC.

Isenhour, C. 2016. Unearthing human progress? Ecomodernism and contrasting definitions of technological progress in the Anthropocene. Economic Anthropology 3: 315-328.

Jackson, T. 2009. Prosperity without growth: economics for a finite planet. New York: Routledge.

Kallis, G. 2015. The left should embrace Degrowth. [accessed August 16, 2016].

Kohl, B. and L. Farthing. 2012. Material constraints to popular imaginaries: the extractive economy and resource nationalism in Bolivia. Political Geography 31(4): 225-235.

Kothari, A. 2014. Radical ecological democracy: a path forward for India and beyond. Development 57(1): 36-45.

Kothari, A., F. Demaria and A. Acosta. 2014. Buen Vivir, degrowth and ecological Swaraj: alternatives to sustainable development and the Green Economy. Development 57(3-4): 362-375. Academia

Krausmann, F., S. Gingrich, H. Haberl, K. Erb, A. Musel, T. Kastner, N. Kohlheb, M. Niedertscheider and E. Schwarzlmüller. 2012. Long-term trajectories of the human appropriation of net primary production: Lessons from six national case studies. Ecological Economics 77: 129-138. Researchgate

Kroll, C. 2015. Sustainable development goals: Are the rich countries ready? Gütersloh: Bertelsmann Foundation.

Lang, M. and D. Mokrani. 2013. Beyond development: alternative visions from Latin America. Quito: Fundación Rosa Luxemburg/Abya Yala Ediciones. (Originally published in Spanish as Mas allá del desarrollo, 2011)

Latouche, S. 2009. Farewell to growth. Malden: Polity Press.

LeBlanc, R.M. 2017. Designing a beautifully poor public: postgrowth community in Italy and Japan. Journal of Political Ecology 24: 449-461.

Lee, R.B. 1968. What hunters do for a living, or, how to make out on scarce resources. In R.B. Lee and I. DeVore (eds.) Man the hunter. Chicago: Aldine.

Lee, R.B. 1979. The !Kung San: men, women and work in a foraging society. Cambridge: Cambridge University Press.

Leopold, A. 1949. A Sand County almanac. New York: Oxford University Press. 
Lockyer, J. 2017. Community, commons, and degrowth at Dancing Rabbit Ecovillage. Journal of Political Ecology 24: 519-542.

Lockyer, J. and J.R. Veteto (eds.) 2013. Environmental anthropology engaging ecotopia: bioregionalism, permaculture, and ecovillages. New York: Berghahn Books.

Malm, A. and A. Hornborg. 2014. The geology of mankind? A critique of the Anthropocene narrative. The Anthropocene Review 1(1): 62-69.

Marcos, S. 2006. The other campaign. San Francisco: City Lights Books.

Martinez-Alier, J. 2003. The environmentalism of the poor: a study of ecological conflicts and valuation. Northampton: Edward Elgar.

Martinez-Alier, J. 2014. Environmentalism, currents of. In D'Alisa, G., F. Demaria and G. Kallis (eds.) Degrowth: a vocabulary for a new era. New York: Routledge.

Martinez-Alier, J., I. Anguelovski, P. Bond, D. Del Bene, F. Demaria, J.F. Gerber, L. Greyl, W. Haas, H. Healy, V. Marín-Burgos, G. Ojo, M. Porto, L. Rijnhout, B. Rodríguez-Labajos, J. Spangenberg, L. Temper, R. Warlenius and I. Yánez. 2014. Between activism and science: grassroots concepts for sustainability coined by Environmental Justice Organizations. Journal of Political Ecology 21: 19-60.

McGuirk, E. 2017. Timebanking in New Zealand as a prefigurative strategy within a wider degrowth movement. Journal of Political Ecology 24: 595-609.

Meadows, D.H., D.L. Meadows, J. Randers and W. Behrens III. 1972. The limits to growth. New York: Universe Books.

Moore Lappé, F. 1971. Diet for a small planet. New York: Ballantine.

Moore, J. Forthcoming. The Capitalocene part II: accumulation by appropriation and the centrality of unpaid work/energy. The Journal of Peasant Studies.

Mountz, A., A. Bonds, B. Mansfield, J. Loyd, J. Hyndman, M. Walton-Roberts, R. Basu, R. Whitson, R. Hawkins, T. Hamilton and W. Curran. 2015. For slow scholarship: a feminist politics of resistance through collective action in the neoliberal university. ACME: An International E-Journal for Critical Geographies 14(4): 1235-1259.

Odum, H.T. 1971. Environment, power and society. Hoboken: Wiley.

Odum, H.T. and E.C. Odum. 2001. A prosperous way down: principles and policies. Boulder: University Press of Colorado.

Otto, J. 2017. Finding common ground: exploring synergies between degrowth and environmental justice in Chiapas, Mexico. Journal of Political Ecology 24: 491-503.

Parra, C and C. Walsh. 2016. Introduction: socialities of nature beyond utopia. Nature and Culture 11(3): 229-238.

Paulson, S. 2013 Masculinidades en movimiento. Transformación territorial y sistemas de género. Buenos Aires: TESEO.

Paulson, S. 2014. Political ecology perspectives on degrowth. In G. D'Alisa, F. Demaria and G. Kallis (eds.) Degrowth: vocabulary for a new era. London: Routledge/Earthscan. Pp. 45-59. Academia

Paulson, S. 2015. Masculinities and femininities in Latin America's uneven development. New York: Routledge.

Porter, M., S. Stern, M. Green. 2016. Social Progress Index 2016. Washington D.C.: Social Progress Imperative.

Piketty, T. and A. Goldhammer. 2015. The economics of inequality. Paris: Éditions La Découverte.

Polanyi, K. 1944. The great transformation. New York: Farrar and Rinehart.

Raskin, P., T. Banuri, G. Gallopín, P. Gutman, A. Hammond, R.W. Kates and R. Swart. 2002. Great transition: the promise and lure of the times ahead. Boston: Stockholm Environment Institute.

Rocheleau, D.E. 2007. Political ecology in the key of policy: from chains of explanation to webs of relation. Geoforum 39: 716-727. 
Rockström, J., W. Steffen, K. Noone, Å. Persson, F.S. Chapin, E.F. Lambin, T.M. Lenton, M. Scheffer, C. Folke, H.J. Schellnhuber, B. Nykvist, C.A. de Wit, T. Hughes, S. van der Leeuw, H. Rodhe, S. Sörlin, P.K. Snyder, R. Constanza, U. Svedin, M. Falkenmark, L. Karlberg, R.W. Corell, V.J. Fabry, J. Hansen, B. Walker, D. Liverman, K. Richardson, P. Crutzen and J.A. Foley. 2009. A safe operating space for humanity. Nature 461 (7263): 472-475.

Rosset, P.M., B. Machín Sosa, A.M. Roque Jaime and D.R. Avila Lozano. 2011. The Campesino-toCampesino agroecology movement of ANAP in Cuba: social process methodology in the construction of sustainable peasant agriculture and food sovereignty. The Journal of Peasant Studies 38(1): 161191.

The Royal Society. 2012. People and the planet report. London: The Royal Society Science Policy Centre.

Sahlins, M. 1972. Stone Age economics. New York: Routledge.

Santos, B. de Sousa. (ed.). 2007. Cognitive justice in a global world: prudent knowledges for a decent life. Lanham: Lexington.

Schneider, F., G. Kallis and J. Martinez-Alier. 2010. Crisis or opportunity? Economic degrowth for social equity and ecological sustainability. Journal of Cleaner Production 18(6): 511-518.

Schor, J.B. 1993. The overworked American: the unexpected decline of leisure. New York: Basic Books.

Schor, J.B. 1999. The overspent American: why we want what we don't need. New York: Basic Books.

Schor, J.B. 2005. Prices and quantities: unsustainable consumption and the global economy. Ecological Economics 55: 309 - 320.

Schumacher, E. F. 1973. Small is beautiful: economics as if people mattered. London: Blond and Briggs.

Sebri, M. 2015. Testing the environmental Kuznets curve hypothesis for water footprint indicator: a crosssectional study. Journal of Environmental Planning and Management 59(11): 1933-1956.

Sekulova, F., G. Kallis, B. Rodríguez-Labajos and F. Scheider. 2013. Degrowth: from theory to practice. Journal of Cleaner Production 38: 1-6.

Sen, A. 1999. Development as freedom. New York: Oxford University Press.

Seth, S. 2009. Putting knowledge in its place: science, colonialism, and the postcolonial. Postcolonial Studies 12(4): 373-388.

Shiva, V. 1988. Staying alive: women, ecology, and survival in India. New Delhi: Kali for Women.

Shiva, V. 2015. Soil not oil: environmental justice in an age of climate crisis. Berkeley: North Atlantic Books.

Singh, S.J. and W. Haas. 2012. Aid, metabolism and social conflicts in the Nicobar Islands. In H. Healy, J. Martinez-Alier, L. Temper, M. Walter and J.F. Gerber (eds.) Ecological economics from the ground up. New York: Routledge/ Earthscan.

Smith-Nonini, S. 2016. The quest for sustainable community economy in North Carolina (and why altruistic thinking won't get us there). Manuscript in preparation.

Spratt, S., A. Simms, E. Neitzert and J. Ryan-Collins. 2009. The great transition. London: New Economics Foundation.

Steffen, W., P.J. Crutzen and J.R. McNeill. 2007. The Anthropocene: Are humans now overwhelming the great forces of nature. AMBIO: A Journal of the Human Environment 36(8): 614-621.

Steffen, W., K. Richardson, J. Rockström, S.E. Cornell, I. Fetzer, E.M. Bennett, R. Biggs, S.R. Carpenter, W. de Vries, C.A. de Wit and C. Folke. 2015. Planetary boundaries: guiding human development on a changing planet. Science 347(6223): 1259855.

Stern, D.I. 2004. The rise and fall of the environmental Kuznets curve. World Development 32(8): 14191439.

Swyngedouw, E. 2015. Depoliticized environments and the promises of the Anthropocene. In E. Swyngedouw and R. Bryant (eds.) International Handbook of Political Ecology. London: Edward Elgar. 
Temper, L., D. del Bene and J. Martinez-Alier. 2015. Mapping the frontiers and front lines of global environmental justice: EJAtlas. Journal of Political Ecology 22: 255-278.

Thaler, R.H. 2000. From homo economicus to homo sapiens. The Journal of Economic Perspectives 14(1): 133-141.

Thinley, J. Y. 2012. Closing Session. Conference of the International Society for Ecological Economics. Rio de Janeiro.

Van den Bergh, J.C. 2011. Environment versus growth—a criticism of "degrowth" and a plea for "a-growth." Ecological Economics 70(5): 881-890.

Van den Bergh, J.C. and G. Kallis. 2012. Growth, a-growth or degrowth to stay within planetary boundaries? Journal of Economic Issues 46(4): 909-920.

Vanhulst, J. and A.E. Beling. 2014. Buen vivir: Emergent discourse within or beyond sustainable development? Ecological Economics 101: 54-63.

Verma, R. 2017. Gross National Happiness in Bhutan: meaning, measure and degrowth in a living development alternative. Journal of Political Ecology 24: 476-490.

Visvanathan, S. 1997. A carnival for science: essays on science, technology and development. London: Oxford University Press.

Wackernagel, M. and W. Rees. 1996. Our ecological footprint: reducing human impact on the earth. Gabriola Island, Canada: New Society Publishers.

Waters, C.N., J. Zalasiewicz, C. Summerhayes, A.D. Barnosky, C. Poirier, A. Gałuszka, A. Cearreta, M. Edgeworth, E.C. Ellis, M. Ellis, C. Jeandel, R. Lainfelder, J.R. McNeill, D.deB. Richter, W. Steffen, J. Syvitske, D. Vidas, M. Wagreich, M. Williams, A. Zhisheng, J. Grinevald, E. Odada, N. Oreskes and A.P. Wolfe. 2016. The Anthropocene is functionally and stratigraphically distinct from the Holocene. Science 351(6269): aad2622.

Walter, M. and J. Martinez-Alier. 2012. Social metabolism, ecologically unequal exchange and resource extraction conflicts in Latin America. Analytical Framework Report. Barcelona: ENGOV.

Watts, M.J. 1983. Silent violence: food, famine, and peasantry in northern Nigeria. Berkeley: University of California Press.

White, R. and C.C. Williams. 2014. Anarchist economic practices in a 'capitalist' society: Some implications for organisation and the future of work. ephermera: theory and politics in organization 14(4): 947971.

Wilkinson, R. and K. Pickett. 2011. The spirit level: why more equal societies almost always do better. New York: Bloomsbury Press.

Zapatista Army of National Liberation. 2005. The sixth declaration of the Selva Lacandona [accessed August 10, 2016]. 